
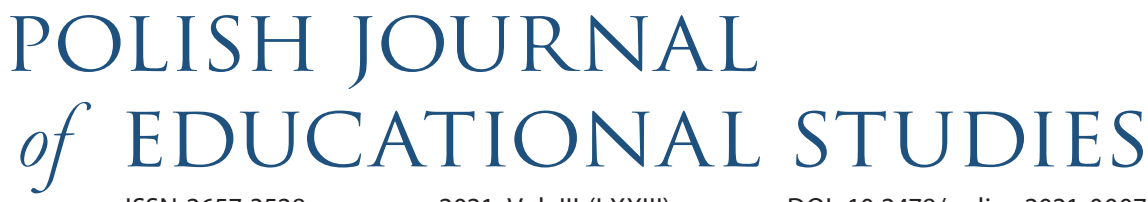

\title{
Anti-discrimination Activities and the Mode of Teaching in the Opinions of Secondary School Students
}

\author{
Urszula Kulikowska'
}

\begin{abstract}
The article examines the issue of anti-discrimination in the context of changes in the teaching mode from classroom to distance schooling. The results of research carried out with the participation of secondary school students will be presented and analysed. The aim of this study is to highlight areas in education that need improvement in order to increase the level of students' comfort in any teaching conditions.
\end{abstract}

KEYWORDS:

anti-discrimination, student, shift

\section{Anti-discrimination}

Discrimination is a multidimensional phenomenon that affects various groups of people. One of its types is that experienced by young people in the school environment. The topic seems to continuously remain timely, therefore all kinds of measures and initiatives are important to prevent or combat discriminatory behaviour in this area. However, can such actions be applied under all conditions? The period of reorganising students' education resulting from the epidemiological situation forced young people to face new experiences in multiple spheres, including socio-emotional. It can therefore be surmised that this situation has given a new context to the issue of antidiscrimination. Therefore, in this article, I have taken up the subject of anti-discrimina-

1 Faculty of Education, University in Bialystok, Poland E-MAIL: urshula.k9@gmail.com ORCID: 0000-0002-3500-7785 
tion from the perspective of shifting the teaching mode, considered strictly from the standpoint of secondary school students.

It stands to reason to begin with the concept of discrimination itself. It is impossible to talk about the effectiveness of any anti-discriminatory measures without knowing the essence of this basic term. Thus, as defined by Wincenty Okoń (2001), discrimination constitutes behaviour that threatens specific groups of people or individuals, not taking into account the full scope of their rights. It is therefore a kind of restriction of the sphere of freedom to which every person is entitled. This approach is reflected in the definition by Władysław Kopaliński (2007), who, within the context of discrimination, draws attention to the deprivation of equal rights from specific groups of people due to their class or religious affiliation or origin. If we refer directly to the school space, discrimination may then be based on factors such as class, religious, racial or economic background. It may originate from both an individual's innate characteristics over which they have no control, known as primary identities, and from secondary identities, which relate to what a given person can decide about, i.e. ones dependent on them. Innate features include gender, skin colour, ethnic origin whereas secondary features encompass, among others, education or religion (Jabłońska, 2017). When discussing discrimination, some key terms that define its character can be identified. Discriminative actions will always be unfair, groundless, harmful and simply negative (Cieślikowska, 2010). It is worth noting that unambiguity in the context of attributing a negative character to discrimination (Nelson, 2003) is no longer obvious when we turn to some sources that assume the possibility of considering it in terms of positive impacts (Poradnik Rzecznika Obywatelskich). It seems no less important that the discrimination mechanism is long-lasting and purposeful (Winiarska and Klaus, 2011). Therefore, we may talk about discriminatory actions when we have reasons to view them as long-term and biased. If we consider the ways by which we infer the presence of discrimination, they are expressed in "direct harm, denial of help, verbal and non-verbal behaviour, overt judging, unfavourable treatment, physical and symbolic violence" (Cieślikowska, 2010, p. 108). Thus, it is not only a passive form of certain behaviours, like isolating or avoiding an individual, but an active deprecating attitude towards the other person (Sztompka, 2005). It should be clearly stated that stereotypes may at times be considered grounds for discrimination. What is more, there is a socalled chain of discrimination, which shows the relationship between three concepts stereotypes, prejudices and discrimination. They are assigned to specific components: prejudices - to the affective component, stereotyping - the cognitive component and discrimination - the behavioural component (Aronson et al., 1997). These individual components are responsible for emotions, thoughts, beliefs and actions, respectively. The discrimination chain mechanism consists in the fact that prejudices arise through the first link, i.e. stereotypes and connecting them with emotions, which becomes the 
basis for specific actions and the emergence of discrimination (Teutsch et al., 2017). However, this correlation need not always exist.

What then is anti-discrimination? The name itself suggests that this concept stands in opposition to discrimination and may be treated as antagonistic in semantic terms. The prefix 'anti' also clearly shows the connection to a concept that is ideologically strongly grounded (Thompson, 2020). Therefore, anti-discrimination is an action or a set of actions aimed at counteracting the mechanisms of discrimination and opposing all its manifestations. Quite similar in meaning here is the term non-discrimination, which is quite often used for the purpose of legal issues (Pisarek, 2016). In this formal context, it is assumed that similar situations are to be treated differently only when it is properly justified, otherwise equality is called for. Anti-discrimination actions can be understood in many ways as they include: anti-discrimination education, discrimination prevention and concrete responses to discrimination (Jonczy-Adamska, 2015). If we refer to selected items in the literature, the term anti-discrimination education is used quite often. According to the Anti-Discrimination Education Society, it is "a conscious action raising awareness, improving skills and influencing attitudes, which is aimed at counteracting discrimination and violence motivated by prejudice and at supporting equality and diversity" (Rawłuszko, 2011, p. 7). It is worth recalling at this point the basic functions of anti-discrimination education, which are: expanding knowledge in the scope of discriminatory processes, exclusion, as well as discriminated groups and emancipation movements, fostering predispositions suitable for counteracting discrimination, giving strength to all those discriminated against through inclusion and empowerment (Rawłuszko, 2011). The idea is essentially to raise awareness about discrimination, encourage taking action in this area, as well as counter the feeling of separateness of people who are already discriminated against or at risk of being victimised in the future. The multidirectionality of the functions listed stems from the need to provide an appropriate broad range of activities, so as to ensure their implementation to the greatest extent possible. All kinds of anti-discrimination education, which can take place within the boundaries of a formal or informal education system, are important. The first group includes various activities pursued at school, and in the case of the second group, actions comprise themed film showcases and social campaigns. The key prerequisite for this type of activities is the right choice of objectives. The educational aspect thereof plays an important role, as well as the requirement that these actions should be known both to the implementer of a given activity and its participants. Anti-discrimination education is carried out by non-governmental organisations and public institutions through three basic types of meetings, namely: training, workshops and training (Rawłuszko, 2011). Their common distinctive feature is the use of active learning methods. 


\section{Methodological basis for the author's own research}

In order to obtain the data necessary for the analysis in the context of the selected thematic area, an online questionnaire survey was carried out among secondary school students - secondary schools of general education and technical schools. The questionnaires were disseminated among the survey participants thanks to the support of selected institutions from different parts of Poland and their commitment to making the research tool available. Additionally, connecting with popular social media influencers and having them share the questionnaire allowed us to gain an even wider range of recipients and increase the size of the respondent group.

The research was intentionally carried out over a specific period, i.e. the month of June 2021. It was the end of the school year and at the same time the period right after shifting the teaching mode, which is related with the intention of obtaining information that would reflect the studied phenomenon as faithfully as possible. The research covered various cities from all over Poland, so as to ensure that the sample is representative. The total sample size stood at 439 persons $(N=439)$. In terms of sex, the distribution was as follows: there were 388 women (88.4\%), and 51 men (11.6\%). In this case, the dominance of the female sex is associated with greater interest of its representatives in participating in the study at the chosen time. The main variables were the type of institution which the respondents frequented, i.e. a secondary school of general education and technical school, respectively. Secondary school students accounted for $71.1 \%$ of all respondents, whereas people attending technical schools $-28.9 \%$.

The subject of the research was the phenomenon of anti-discrimination from the perspective of changing the teaching mode in the opinions of secondary school students. The main goals set for the implementation of the research were: to compare the forms of anti-discrimination activities in classroom and distance learning, to find out respondents' opinions in this regard, and thus to indicate the resulting ideas for improving the situation at a selected educational level. Research problems to which answers will be sought in the course of the research include: Whether and how the frequency of participation of the respondents in anti-discrimination activities changed depending on the mode of education? What forms of anti-discrimination activities did the respondents encounter in classroom and distance teaching? 


\section{The results of research on the perception of the phenomenon of anti-discrimination}

One of the issues included in the study was the frequency of participation in anti-discrimination activities during both distance and classroom teaching. In order to obtain a completely subjective perception of this category, the respondents themselves had to interpret the scope of anti-discrimination measures when answering this question. The data obtained from the respondents in the context of classroom teaching is presented in the chart below.

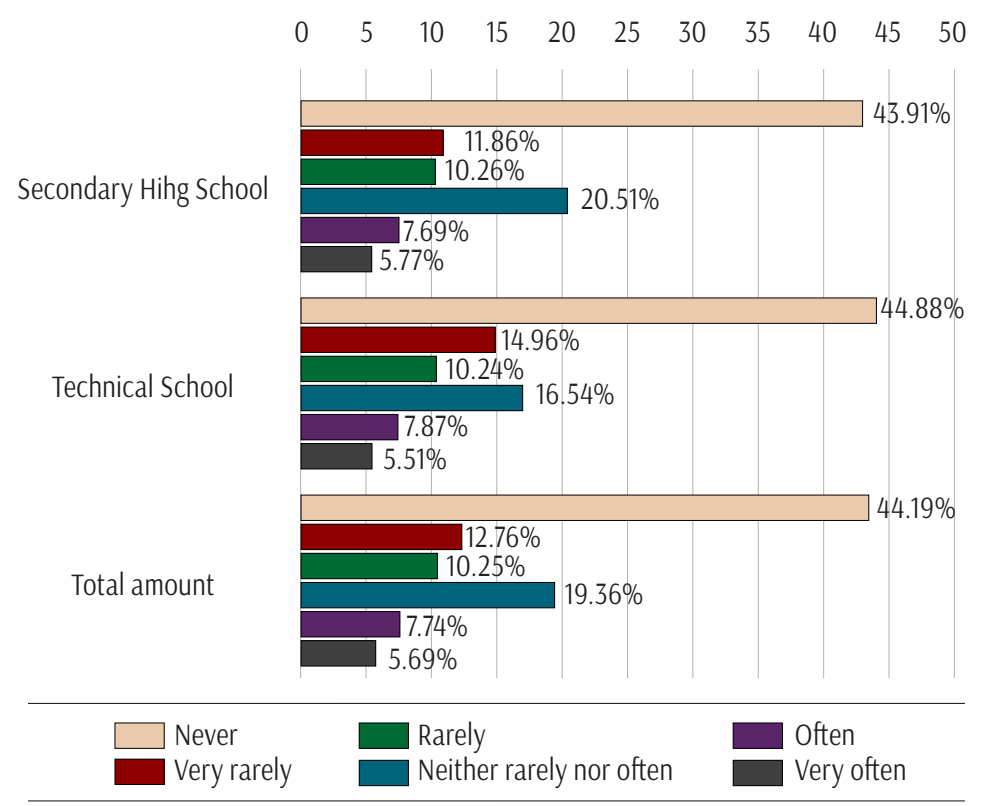

Figure 1. Frequency of participation in anti-discrimination activities during full-time teaching

The statement "never" was the prevailing answer among the respondents, both among secondary school and technical school students. Almost half of the respondents in both groups have never participated in classroom anti-discrimination activities. In the case of secondary school it was $43.91 \%$, and in technical school $-44.88 \%$. If we look at the categories "rarely" or "very rarely" among the general secondary school students surveyed, another $22.12 \%$ were involved in anti-discrimination activities to a limited extent. Technical school students' responses are quite similar and constitute $25.2 \%$ of all responses in this group. On the other hand, $20.51 \%$ of general secondary school students and $16.54 \%$ of technical school students rated their participation as moderate. 
The last two variants of answers appear to be crucial in terms of anti-discrimination, showing the percentage of people most committed to anti-discrimination initiatives during learning that takes place in a traditional setting.

In this comparison, there are no significant differences between the percentage ratio in the two types of schools; in fact, one could even argue that it is on the same level. In secondary school, $13.46 \%$ of the surveyed students often or very often participate in anti-discrimination activities, while in technical schools it is $13.38 \%$. Taking into account the distribution of answers in particular categories, one may notice signals of sorts pointing to insufficient involvement of students in anti-discrimination activities in the schools they attend, the reasons for which may be found perhaps in the low level of motivation to participate in them. On the other hand, this situation may arise as a result of negligence or a limited number of such activities offered to the charges by the institutions. It is here that the aforementioned anti-discrimination education should play a major role, which, apart from providing concrete didactic content, may affect the development of skills needed to prevent and respond to discrimination (Świerszcz 2015).

It is worth comparing the situation related to teaching in the classroom education mode with the results concerning distance learning. The answers given by the respondents in this context are presented in the chart below.

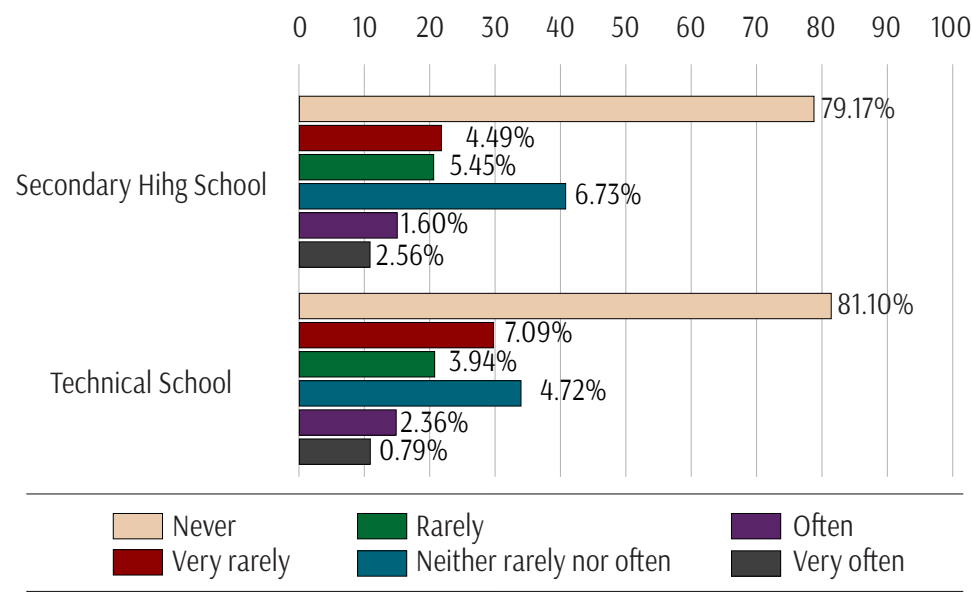

Figure 2. Frequency of participation in anti-discrimination activities during distance learning

The overwhelmingly dominant response among respondents is one showing that they have never engaged in anti-discrimination activities during distance learning. Such a response was given by $79.1 \%$ of secondary school students and $81.1 \%$ of technical school students. It should be noted that this is a much higher result in this cat- 
egory compared to the data obtained for the same question in the classroom teaching mode. Again, the respondents from technical schools rate higher by a small percentage compared to secondary school students, citing the answer "never" more often to this question. As for the moderate degree of respondents' involvement in this type of activities, in the case of secondary school students it is $6.73 \%$, and in the group of technical school students it is $4.72 \%$. Responses to the frequent and very frequent participation in anti-discrimination activities during distance learning appear to a small, even minimal extent among the respondents from both types of schools. This answer was cited by $4.16 \%$ of secondary school students and $3.15 \%$ of technical school students. This differs from the results in the same category in the classroom mode in that the discrepancy between the responses from each type of school was somewhat less noticeable. In this case, a few more secondary school students rate their participation in remote anti-discrimination activities as frequent and very frequent. By comparing all the obtained results with the data on the classroom teaching mode, we may notice a significant drop in the frequency with which secondary-level students participate in anti-discrimination activities in the distance learning mode. This may be due to the unique character of this particular period related to the need to adapt to new teaching conditions and to focus more on the organisational sphere of classes than on activities in the area of social and emotional functioning of the students. Nevertheless, the situation related to the new teaching mode carries the risk of certain negative consequences for students, posing, among others, a serious threat to peer relations. All the more so, it is worth tending to their psychological comfort and eliminating any discriminatory mechanisms that may also occur in the digital space with great intensity. Undoubtedly, the wide range and availability of digital technology tools create opportunities to successfully conduct such anti-discrimination activities.

One of the issues mentioned in the questionnaire involved forms of action aimed at preventing peer violence. The question is relevant because violence may be a manifestation of discrimination, and this gives the research perspective a broader reach. The respondents' task was to present their own proposals in this area. Various examples were given, and their detailed analysis allowed for the identification of key categories that dominated among the respondents. They are presented in the table 1. 
Table 1. Forms of measures to prevent peer violence known to the respondents

\begin{tabular}{|c|c|c|}
\hline \multicolumn{3}{|c|}{ What forms of peer violence prevention activities do you know? } \\
\hline \multirow{3}{*}{ Response category } & \multicolumn{2}{|c|}{ Type of school } \\
\hline & $\begin{array}{l}\text { General Second- } \\
\text { ary School }\end{array}$ & Technical School \\
\hline & \multicolumn{2}{|c|}{ Percentage result } \\
\hline Communication (conversation) & $25.6 \%$ & $22.8 \%$ \\
\hline Help from a psychologist, educator & $10.9 \%$ & $7.1 \%$ \\
\hline Help from another adult (including a teacher) & $9.6 \%$ & $6.3 \%$ \\
\hline $\begin{array}{l}\text { Educational forms (e.g. workshops, extracurricular } \\
\text { activities) }\end{array}$ & $20.2 \%$ & $9.4 \%$ \\
\hline Peer integration & $1 \%$ & $4 \%$ \\
\hline $\begin{array}{l}\text { Enforcing consequences against perpetrators of } \\
\text { violence }\end{array}$ & $1.6 \%$ & $2.4 \%$ \\
\hline Responding to violent situations & $9.3 \%$ & $9.4 \%$ \\
\hline No opinion & $13.1 \%$ & $31.5 \%$ \\
\hline Other & $8.7 \%$ & $7.1 \%$ \\
\hline
\end{tabular}

Communication was the most common response category. This is true for two types of educational facilities, with technical schools having the highest percentage of respondents (31.49\%) who did not express any opinion on this subject. Conversation as a form of action to prevent peer violence was indicated by $25.64 \%$ of secondary school students and $22.83 \%$ of technical school students. Thus, this form of communication seemed to the respondents to be the most obvious choice of action to prevent peer violence. We could say that the result falls within the standards of the effectiveness sphere. However, one should bear in mind that this form should not dominate all kinds of other anti-discrimination initiatives, because in this case it would be inadvisable to minimise the scope of other practical actions targeting discrimination.

Another category that ranked equally high compared to other responses were educational forms, which included examples of activities such as: extracurricular activities, educational campaigns, workshops and lectures. This indicates a high level of awareness among the respondents about education on the subject matter. Secondary school students who responded this way constituted $20.19 \%$, and those studying in technical schools accounted for $9.44 \%$. The exact same percentage of people from this group indicated another form, namely reacting to violent situations. Such responses were given by secondary school students with a similar frequency and constituted $9.29 \%$. There were relatively frequent responses referring to assistance provided for violence prevention, both by professionals and those around students. The surveyed youth are therefore aware of who to turn to in difficult moments and how important such meetings are. The help of a psychologist or educator was indicated by $10.89 \%$ of secondary school students, whereas the help of another adult was indicated by 
9.61\% of people from this group. Meanwhile, in the case of technical schools, $7.08 \%$ of students referred to the assistance of a psychologist and educator, while $6.29 \%$ of students to the help of another adult. The respondents' proposals also mention integration activities intended to shape proper peer relations. The category of peer integration was indicated in the answers of $0.96 \%$ of secondary school students and $3.93 \%$ of technical school students. Another key category for the examined issue was distinguished, namely enforcing consequences against perpetrators of violence, such as meting out punishments or reprimanding the culprit. Within this framework, the proposals of $1.6 \%$ of secondary school students and $2.36 \%$ of technical school students were taken into account. In the context of the forms of actions to prevent peer violence, it can be stated that they are understood by the respondents in a multifaceted way and often demonstrate a high degree of reflection on their part.

\section{Forms of anti-discrimination activities as perceived by the respondents}

The questionnaire also included questions about specific forms of activities that respondents encountered both during classroom and distance learning. In order to show the fundamental differences between the two teaching modes and the convergence of the identified categories, the collected data was compiled in the form of a single table.

Table 2. Forms of anti-discrimination activities during classroom and distance learning

\begin{tabular}{lcccc}
\hline What forms of anti-discrimination activities have you encountered while studying? \\
\hline & $\begin{array}{c}\text { Secondary School of } \\
\text { Response category }\end{array}$ & \multicolumn{2}{c}{ Technical School } \\
\cline { 2 - 5 } & $\begin{array}{c}\text { Classroom } \\
\text { Mode }\end{array}$ & $\begin{array}{c}\text { Distance } \\
\text { Mode }\end{array}$ & $\begin{array}{c}\text { Classroom } \\
\text { Mode }\end{array}$ & $\begin{array}{c}\text { Distance } \\
\text { Mode }\end{array}$ \\
\cline { 2 - 5 } & \multicolumn{4}{c}{ Percentage result } \\
\hline Communication/Conversation & $10.6 \%$ & $8 \%$ & $9.4 \%$ & $7 \%$ \\
\hline Help from a psychologist, educator & $9.3 \%$ & $3.8 \%$ & $4.7 \%$ & $0.8 \%$ \\
\hline Help from another adult (including & $3.2 \%$ & $3.5 \%$ & $1.6 \%$ & $0 \%$ \\
\hline a teacher) & $17.6 \%$ & $8.3 \%$ & $8.7 \%$ & $0 \%$ \\
\hline Educational forms & $4.5 \%$ & $2.9 \%$ & $2.4 \%$ & $0 \%$ \\
\hline Responding to violent situations & $34 \%$ & $47.8 \%$ & $37 \%$ & $51.3 \%$ \\
\hline Did not occur & $18.9 \%$ & $20.6 \%$ & $33.1 \%$ & $33.9 \%$ \\
\hline No response & $1.9 \%$ & $5.1 \%$ & $3.1 \%$ & $7 \%$ \\
\hline Other & & & & \\
\hline
\end{tabular}


According to the respondents, the categories of communication and educational forms are dominant in the classroom teaching mode. The first question covers the responses of $10.6 \%$ of secondary school students and $9.4 \%$ of technical school students. Educational forms were indicated by $17.6 \%$ of secondary school students and $8.7 \%$ of those attending technical schools. For comparison, in distance mode these categories show significant declines and sometimes do not exist at all. This is the case, for example, with the item related to educating students, which cannot be taken into account based on the answers given by individuals learning in technical schools. Although with a markedly downward trend relative to the classroom mode of learning, communication in the distance mode is perceived by the respondents of both types of schools at a similar level. It accounts for $8 \%$ among secondary school students, and $7 \%$ among technical school students. It is important to note that communication as an anti-discrimination measure in distance mode is of a somewhat different character. The respondents cite examples such as conversations, online sessions and the use of social networks, among others. In the case of technical school students, one should refrain from talking about yet other categories, which remain at a zero level. These are: help from another adult and responding to violent situations. According to the percentages, the former category increases slightly in remote mode, from $3.2 \%$ to $3.5 \%$ to be precise. The adverse correlations are evidenced by the high level of the "did not occur" category in the distance learning mode, which is higher than in the classroom mode and amounts to $34 \%$ (high school) and 37\% (technical school), respectively. During distance learning it totalled $47.8 \%$ (high school) and $51.3 \%$ (technical college). The respondents sometimes give the reasons for the lack of anti-discrimination measures applied during distance learning, pointing to the neglect and ignoring of certain situations by various educational entities, or the absence of a clear rationale for doing so.

Also included in the research was secondary school students' perception of the very need for peer violence prevention efforts at school. The assessment made by the respondents is presented in the chart below.

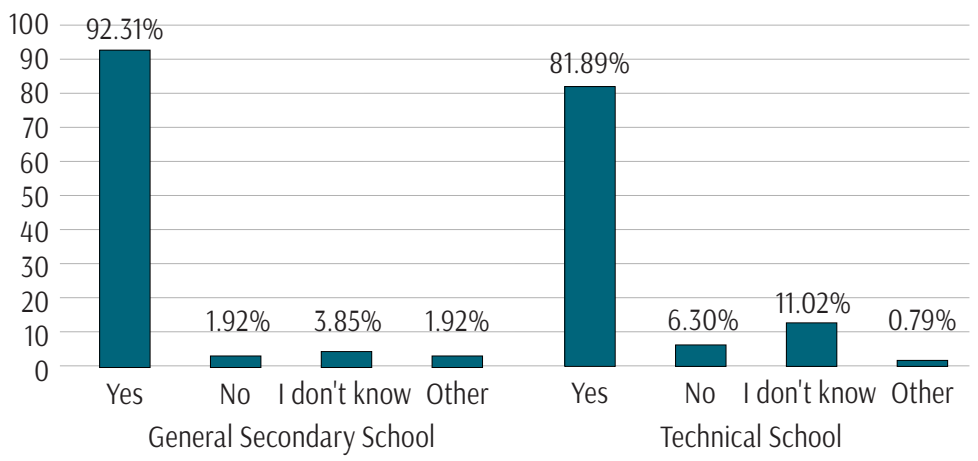

Figure 3. Assessment of the need for actions to prevent peer violence 
Most of the respondents attending both general and technical secondary schools admit that such activities are needed. An affirmative answer among secondary school students was given by $92.31 \%$, and in the case of technical schools it was $81.89 \%$. Comparing both types of institutions, one may notice that slightly fewer students of technical schools answered the question affirmatively ("yes"). However, the difference is nevertheless minor. It is puzzling and disturbing at the same time that as many as $11.02 \%$ of the surveyed technical school students have doubts as to whether there is really a need for measures to prevent peer violence. Moreover, compared to their secondary school peers in the study, they are much more likely to not recognise the need for anti-bullying activities. This raises a question that encourages you to think about what this may result from and to look for possible solutions to this situation.

\section{Summary}

The issues related to anti-discrimination in the context of schooling provide an extensive field for possible analysis and steps to improve education as a whole. The conclusions drawn from the research reveal a disturbing tendency that distance learning entails greater passivity also in terms of anti-discrimination, which does not cease to exist in this mode but only changes its form. In terms of frequency of participation of the respondents in anti-discrimination activities, a slightly higher value is observed for classroom teaching. The forms of anti-discrimination measures proposed by the respondents in this case include: communication, help from a professional, help from another adult, educational forms and responses to violent situations. Their percentages vary slightly depending on the learning mode, but the differences are not that significant.

The topic of anti-discrimination is extremely important and much needed because, as the research results show, changes in the education system may have a strong impact on the situation of young people and give a new context to their experiences. The difficulties that they are sometimes faced with in their everyday lives do not subside, but change in form. Such is the case with discrimination and, consequently, also with anti-discrimination. All kinds of related activities that have so far been undertaken as part of traditional classroom schooling should be transplanted into the new realities of distance education. The essence here is to instigate changes in the attitudes of students and to embed in their consciousness the fundamental values of equality and respect for every human being. It is therefore worth helping students by offering appropriate actions that support their commitment to preventing and eliminating the manifestations of discrimination. For that reason, the role of teachers and educators within the framework of anti-discrimination education may be to run classes convey- 
ing an appropriate message, themed workshops, simulation exercises alongside various other ways of working with students. It is also important to refer to the level of awareness and state of preparation of the teachers themselves. The effectiveness of anti-discrimination education in distance learning will certainly be affected by their participation in trainings dedicated to teachers or courses containing valuable tips for conducting lessons and attractive teaching techniques.

\section{References}

Aronson, E., Wilson, T. D., \& Akert, R. M. (1997). Psychologia społeczna. Serce i rozum. Wydawnictwo Zysk i S-ka.

Benner, A.D., \& Graham, S. (2013). The antecedents and consequences of racial/ethnic discrimination during adolescence: Does the source of discrimination matter? Developmental Psychology, 49(8), 1602-1613. DOI: 10.1037/a0030557.

Branka, M., \& Cieślikowska, D. (Eds.). (2010). Edukacja antydyskryminacyjna. Podręcznik trenerski. Stowarzyszenie Villa Decjusza.

Gaias, M.L., Gal-Szabo, E.D., Shivers, M.A., \& Kiche, S. (2021). From Laissez- Faire to AntiDiscrimination: How Are Race/Ethnicity, Culture, and Bias Integrated into Multiple Domains of Practise in Early Childhood Education?. Journal of Research in Childhood Education. DOI: 10.1080/02568543.2021.1951403.

Jabłońska, Z. (2017). Dyskryminacja - wprowadzenie do pojęcia. W: K. Kędziora \& K. Śmiszek (Eds.), Ustawa o wdrożeniu niektórych przepisów Unii Europejskiej w zakresie równego traktowania. Komentarz (s. 17-41). Wolters Kluwer.

Jonczy-Adamska, M. (2015). Rzecz o działaniach antydyskryminacyjnych. Retrieved from: http://edukacjaidialog.pl/publikacje/rzecz_o_dzialaniach_antydyskryminacyjnych,482.html [accessed: December 3, 2021].

Kopaliński, W. (2007). Słownik wyrazów obcych i zwrotów obcojęzycznych z almanachem. Oficyna Wydawnicza RYTM.

Nelson, T.D. (2003). Psychologia uprzedzeń. Gdańskie Wydawnictwo Psychologiczne.

Okoń, W. (2001). Nowy słownik pedagogiczny. Wydawnictwo Akademickie „Żak”.

Pisarek, A. (2016). Zasada parytetu płci jako zabezpieczenie funkcjonowania zasady równouprawnienia kobiet i mężczyzn w Unii Europejskiej. W: M. Kępa \& M. Marszał (Eds.), Duch praw w krajach Europy Środkowo-Wschodniej. https://repozytorium.uni.wroc. pl/dlibra/doccontent?id=79174 (accessed: December 3, 2021).

Rawłuszko, M. (Ed.) (2011). Edukacja antydyskryminacyjna i jej standardy jakościowe. Towarzystwo Edukacji Anty-dyskryminacyjnej.

Sztompka, P. (2005). Socjologia. Analiza społeczeństwa. Wydawnictwo Znak.

Świerszcz, J. (2015). Przeciwdziałanie dyskryminacji w szkole i zapewnienie równego traktowania wedukacji. Retrieved from: https://kph.org.pl/wp-content/uploads/2016/03/2015_ Publ-pokonf_Rowna-S (accessed: December 3, 2021).

Teutsch, A., Stoch, M., \& Kozakoszczak, K. (2017). Opracowanie merytoryczne na temat przeciwdziałania dyskryminacji i przemocy motywowanej uprzedzeniami dla studentów, stu- 
dentek, doktorantów, doktorantek, nauczycieli i nauczycielek szkół wyższych. Fundacja Autonomia.

Thompson, N. (2020). Anti-Discriminatory Practise: Equality, Diversity and Social Justice (Practical Social Work Series). Red Globe Press.

Trociuk, S. (Ed.) (2013). Przeciw dyskryminacji. Poradnik Rzecznika Praw Obywatelskich. Biuro Rzecznika Praw Obywatelskich.

Turnsek, N. (2013). Enjoying cultural differences assists teachers in learning about diversity and equality. An evaluation of antidiscrimiantion and diversity training. CEPS Journal, 3(4), 117-138. DOI: 10.25656/01:8504.

Winiarska, A., \& Klaus, W. (2011). Dyskryminacja i nierówne traktowanie jako zjawisko społeczno-kulturowe. W: B. Kłos \& J. Szymańczyk (Eds.), Zasada Równości i zasada niedyskrymiancji. Studia BAS, 2(26). Wydawnictwo Sejmowe Kancelarii Sejmu. 